\title{
RURAL FARMERS' COPING STRATEGIES TO EFFECTS OF CLIMATE CHANGE ON WATERMELON PRODUCTION IN IGBOORA, OYO STATE, NIGERIA
}

\author{
Dyediran, W. O. ${ }^{1+}$ \\ Domoare, A. M. ${ }^{2}$ \\ Alaka, F. A. ${ }^{3}$ \\ Shobowale, A. A. ${ }^{4}$ \\ Oladoyinbo, O. B. ${ }^{5}$
}

\author{
${ }^{\prime}$ Department of Agricultural Extension and Rural Development, Federal \\ University of Agriculture, Abeokuta, Ogun State, Nigeria \\ ${ }^{2}$ Email:ovediran_wasiu@yahoo.com Tel:+2348053171938 \\ ${ }^{2}$ Department of Agricultural Education, Federal College of Education, \\ Abeokuta, Ogun State, Nigeria \\ ${ }^{2}$ Email:avodejiomoare@gmail.com Tel: +2349052282231 \\ ${ }^{3,4}$ Department of Agricultural Education, Federal College of Education \\ (Special), Oyo town, Oyo State, Nigeria \\ ${ }^{3}$ Email:favoade@gmail.com Tel: +2348033599347 \\ ${ }^{4}$ Email:joktifun@gmail.com Tel:+2348062456382 \\ ${ }^{5}$ Department of Agricultural Extension and Farm Management, Oyo State \\ College of Agriculture, Igboora, Oyo State, Nigeria \\ ${ }^{5}$ Email:seunoladovinbo@gmail.com Tel:+2348054589544
}

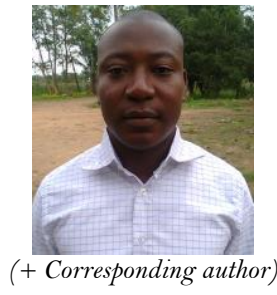

ABSTRACT

\section{Article History}

Received: 5 December 2017

Revised: 28 June 2018

Accepted: 3 July 2018

Published: 6 July 2018

\section{Keywords}

Rural farmers

Watermelon

Production

Coping strategies

Climate change

Effect.

Igboora

Livelihood

Nigeria.

\begin{abstract}
In the past two decades watermelon production has been a major source of livelihood sustainability in the rural farming system especially among the younger farmers. In recent time however, climate change has threatened and undermined this potential. This study was therefore carried out to assess rural farmers' coping strategies to effects of climate change on watermelon production in Igboora, Oyo State, Nigeria. Multi stage sampling technique was used to select 150 watermelon farmers as sample size for this study. Descriptive statistics and chi-square analysis were used to analyse the data. The findings showed that there was significant relationship between respondent's personal characteristics and coping strategies adopted by the watermelon farmers at $\mathrm{p}$ $<0.05$ level. Also, there was significant relationship between sources of information and coping strategies adopted by the watermelon farmers at $p<0.05$ level. It is hereby recommends that effort should be put in place by the government and Seed Council of Nigeria (SCN) to come up with improved, and high drought and disease resistant watermelon seeds to increase productivity and reduce cost of seeds importation in the study area.
\end{abstract}

Contribution/Originality: The paper's primary contribution is finding that watermelon farmers combined both scientific and indigenous farming strategies to cope with adverse effects of climate change.

\section{INTRODUCTION}

Watermelon (Citrullus lanatus) is grown commercially in areas with long frost free warm periods (Prohens and Nuez, 2008). China, Turkey, Iran, Brazil, United States, Egypt and Russian Federation are the major watermelon producers (Food and Agriculture Organization (FAO), 2010). Two decades ago watermelon was introduced into rural farming system in Nigeria, and it grows well both in the humid and drier savanna agro-ecologies. The crop is cultivated twice a year with high productivity and income that encourages many farmers to go into its production. Unlike in advanced countries where watermelon is utilized for the production of juices, nectars and fruit cocktails (Wani et al., 2008) it is eaten as raw fruit in both rural and urban centres in Nigeria. From the East to the Central and far North in Ibarapa Areas of Oyo State, Nigeria the youth are predominant in watermelon production because 
of its quick returns on investment. Thus, it contributes immensely to the livelihood sustainability of both young and older farmers. In recent time however, there has been continuous decline in watermelon output and in worst situation total crop failure is recorded which constituted great economic losses to the farmers due to the detrimental effect of the climate change. This has greatly affected many rural households that depend on watermelon production for living. It affects rural economic and social systems as youths are leaving farms to cities to do commercial motorcycling (okada) and other petty jobs therefore leaving behind women and old people in the farms. The climate change is threatening biodiversity and human well-being (Williams et al., 2008; Cardinale, 2012). In Nigeria, continuous decline in crop yield and food crop production due to reduction in rainfall and relative humidity and increase in temperature has been observed (Agboola and Ojeleye, 2007). Like other developing countries, the challenge of climate change and global warming is enormous in Nigeria as a result of communication gap between the research centres, extension and farmers in one part and poor funding of research by the government on the other part. Recognizing that Nigeria is confronted by major environmental problems and every climate study indicate that Nigeria is one of the countries that are vulnerable to climate change (Obioha, 2008) make this study becomes necessary. According to the Intergovernmental Panel on Climate Change (2007) yield from rain fed agriculture could be reduced up to $50 \%$ by the year 2020 in some African countries. It estimates that Africa will be the most vulnerable to climate change globally, due to the multiple stresses of poor infrastructure, poverty and governance. Temperatures are likely to increase by between $1.5-4^{\circ} \mathrm{c}$ in this century. The resultant of temperature and precipitation variations in Africa would be high crop pests and diseases and soil degradation. Challinor et al. (2014) reported that even at low $\left(+2^{\circ} \mathrm{C}\right)$ level of warming, agricultural productivity is likely to decline across the globe, but particularly across tropical areas. Projections on yield reduction show a drop of up to $50 \%$ and crop revenue is forecast to fall by as much as $90 \%$ by 2100 (FAO, 2009). Declining incomes and rising unemployment are expected to hit agriculture zones in combination to worsening health. A fall in nutrient access is likely to raise susceptibility to diseases such as malaria and HIV/AIDS (FAO, 2009). The ever rising problem of climate change is becoming more threatening to sustainable economic development and the totality of human existence (Adejumo, 2004) especially in the rural settings. While watermelon farmers are generally experiencing climate change and consequently they are counting their losses, many farmers however have developed coping mechanism to minimize the effect of climate change and thrive in watermelon production. Awareness, enlightenment and training on the impact of climate change and necessary coping strategies to be used are generally lacking at the grassroots. Also, there is little empirical study to fill this gap and help thousands of watermelon farmers survive the insurmountable problems of climate change in the rural areas. In Nigeria, the focus of researches on climate change and coping strategies has been on cash and arable crops with less attention on horticultural crops like melon, cucumber and watermelon. This study therefore found it important to look into rural farmers coping strategies to effect of climate change on watermelon production in Oyo State, Nigeria as this will not only checkmate the production losses but it will also have multiplier effect on the availability, market supply and consumption of nutritious watermelon.

\section{The Specific Objectives of the Study are to:}

i. describe the personal characteristics of the watermelon farmers in the study area

ii. assess the effect of climate change on watermelon production in the study area

iii. identify the various coping strategies adopted by the watermelon farmers in the study area

iv. examine the various sources of information on coping strategies to climate change in the study area

\section{Hypotheses of the Study are stated in Null Forms As:}

$\mathrm{H}_{01}$ : There is no significant association between respondent's personal characteristics and coping strategies adopted $\mathrm{H}_{02}$ : There is no significant relationship between sources of information and coping strategies adopted 


\section{MATERIALS AND METHODOLOGY}

The study was conducted in Oyo State, Nigeria. Population of the study was all watermelon farmers in Oyo State. A multi stage sampling technique was used in selecting respondents for this study. Igboora was purposively selected based on the a priori information that in recent time large proportion of rural household in the communities cultivated watermelon. Igboora has good vegetation for horticultural crops because prior to the introduction of watermelon almost all the inhabitants were cultivating melon. The second stage was random selection of two blocks out of three blocks in Igboora. In the third stage, five villages were randomly selected from the selected blocks making ten villages (Abukele, Apaara, Oloori, Lanyonu, Obatade, Tobalogbo, Fedegbo, Jaagun, Ayelogun, and Alaagba). Fifteen (15) watermelon farmers were randomly selected from each of the selected villages through their register list and it gave a total of 150 respondents as sample size for this study.

\subsection{Validity and Reliability Test}

Data were collected with interview guide and observations. The instrument used for the data collection was subjected to face validity by consulting experts in the field of Agricultural Extension and Rural Development. Items found ambiguous were removed. Test re-test was carried out with thirty (30) watermelon farmers in Eruwa community at an interval of two weeks to ascertain the reliability of the instrument. A reliability coefficient of 0.91 was obtained which is above the reliability coefficient of 0.75 indicating high internal consistency of the instrument used for this study. Hence, the instrument used for this study was reliable.

\subsection{Measurement of Variables}

Age, farm size, household size and farming experience were measured at ratio level while sex and educational level were measured at nominal level. Effects of climate change on watermelon production were measured using a 3-point rating scale of High effect (3), Moderate effect (2), Low effect. Coping strategies used by the respondents were also measured as Always used (3), Seldom used (2), Not used (1) and ranked in order of priority.

\subsection{Method of Data Analysis}

Descriptive statistics such as frequency counts, percentage, and mean was used to analyze the objectives while chi-square analysis was used to test the proposed hypotheses.

\section{RESULTS AND DISCUSSION}

\subsection{Socio-economic Characteristics of Respondents}

The result reveals that majority (77.3\%) of the respondents were between $31-40$ years old while few $(9.3 \%)$ were above 41 years of age. The mean age of the respondents was 35.1 years. This reveals the presence of young and middle aged individuals who are known to be active and innovative. The respondents are within the economically active part of the population. Majority of the respondents (96\%) were males while only $4 \%$ were females. This is an indication that men have predominance in watermelon production in the study area. This is not unconnected with the fact that men are more involved in cultivation and harvesting activities while women carry out post-harvesting activities and marketing of farm produce. This finding concurs with that of Oyediran et al. (2016) that men are usually engaged in land tilling and crop cultivation while women are known for postproduction and marketing activities. Many of the respondents (46.7\%) had secondary school education while $38.6 \%$ attended primary school. Only $6.7 \%$ did not have formal education. This shows that the farmers had some level of formal education in the study area which may in turn affect the rate of adoption of modern farming practices in watermelon production. The result also indicates that $61.3 \%$ of the respondents had grown watermelon for $6-10$ years while $14.70 \%$ had been in watermelon cultivation for more than 11 years before shifting to watermelon farming. The mean year of farming experiences was 7.53 years. This further shows that watermelon production and 
other horticultural crops are not new to the farmers in the study area. Majority of the respondents (80\%) cultivated more than 3 ha of land while $20 \%$ cultivated $1-2$ ha. The average farm size was 3.10 ha. This shows that most of the respondents are peasant farmers.

Table-1. Distribution of respondents based on their socio-economic characteristics $(n=150)$

\begin{tabular}{l|l|l|l}
\hline Variables & Frequency & Percentage (\%) & Mean \\
\hline Age (years) & & & \\
\hline$\geq 30$ & 20 & 13.3 & 35.10 \\
\hline $31-$ O & 116 & 77.3 & \\
\hline 41 and ab ve & 14 & 9.3 & \\
\hline Sex & & 96.0 & \\
\hline Male & 144 & 4.0 & \\
\hline Female & 06 & & \\
\hline Educational status & & 6.7 & \\
\hline No formal edu ation & 10 & 38.6 & \\
\hline Primary education & 58 & 46.7 & \\
\hline Secondary education & 70 & 8.0 & \\
\hline Tertiary education & 1 & & 7.53 \\
\hline Farming experience years) & & 24.0 & \\
\hline$\geq 5$ & 36 & 61. & 3.10 \\
\hline $6-10$ & 92 & 14.7 & \\
\hline 11 and above & 22 & 20.0 & \\
\hline Farm size (ha) & & 80.0 & \\
\hline $1-2$ & 30 & & \\
\hline 3 and above & 120 & \\
\hline Source: Field survey, 2016 & & \\
\hline
\end{tabular}

\subsection{Effects of Climate Change on Watermelon Production}

Table 2 results showed that majority $(87.4 \%)$ of the respondents' experienced low sales and reduced income which resulted from the small size of pods and low yield (84.7\%). These results support the findings of Oyekale (2009) that watermelon is highly sensitive to changes in climate from hours of sunshine to rainfall and application of water, soil condition and particularly to temperature due to effects on evapo-transpiration. The climate change has also led to reduction in pods formation on the field (70.0\%) and large proportion of damaged pods. Similarly, high incidence of pest and diseases $(62.3 \%)$ was reported by the respondents.

Table-2. Effects of climate change on watermelon production $(n=150)$

\begin{tabular}{|c|c|c|c|c|c|}
\hline Effect of climate change & High effect & Moderate effect & Low effect & Mean & Rank \\
\hline Increase in pest and disease infestation & $94(62.6)$ & $41(27.3)$ & $15(10.0)$ & 2.51 & $5^{\text {th }}$ \\
\hline High occurrence of damaged pods & $98(65.3)$ & $32(21.3)$ & $20(13.4)$ & 2.52 & $4^{\text {th }}$ \\
\hline Decrease in watermelon pods formation & $105(70.0)$ & $24(16.0)$ & $21(14.0)$ & 2.56 & $3^{\text {rd }}$ \\
\hline Reduced pods size and low yield & $127(84.7)$ & $16(10.7)$ & $07(4.6)$ & 2.80 & $2^{\text {nd }}$ \\
\hline Complete drying off before fruiting & $95(63.3)$ & $30(20.0)$ & $25(16.7)$ & 2.47 & $6^{\text {th }}$ \\
\hline Reduced sales and income & $131(87.4)$ & $14(9.3)$ & $05(3.3)$ & 2.84 & $1^{\text {st }}$ \\
\hline
\end{tabular}

Source: Field survey, 2016

Figures in parenthesis are percentages

\subsection{Coping Strategies Adopted}

Watermelon farmers use different coping strategies to overcome effect of climate change. Dry season has been the preferred period of planting watermelon by the farmers due to experience of excessive rainfall that support rapid spread of pest and diseases, disrupt vines formation and wash away the flowers during raining season. Farmers have adjusted planting time to dry season around $1-10$, September of planting season $(\overline{\mathbf{X}}=2.79)$. However, dry season also has its challenge of limited rainfall and even prolonged drought. This is evidenced in the 
late arrival of rain, the drying-up of stream and Small Rivers that usually flows year round, the seasonal shifting of the "Mango rains" and of the fruiting period (Adebayo, 2012). Many watermelon farmers expanded planting space from $90 \mathrm{~cm} \times 90 \mathrm{~cm}$ apart to $1 \mathrm{~m} \times 1 \mathrm{~m}$ to allow rapid vines development $(\overline{\mathbf{X}}=2.48)$. The farmers has also adopted the use of foreign seeds which come in a sealed tin (100mg and 500mg) as against the use of local seeds $(\overline{\mathbf{X}}=2.33)$. Inorganic fertilizer (urea) is applied at exactly 2 weeks or 16 days after planting to speed up the growth and development of the crop against vagary of weather and poor soil fertility $(\overline{\mathbf{X}}=2.59)$; the fertilizer used has increased from 2 bags to 3 bags/ha. Folia fertilizer is mixed with fungicide and insecticide and sprayed consistently at 8 days interval for $5-6$ weeks $(\overline{\mathbf{X}}=2.41)$. The spraying is seized at the emergence of pods formation which is about $8-9$ weeks after planting. Folia fertilizer is applied to boost the pods formation while fungicide and insecticide are used to prevent pest and diseases interference on the watermelon farms. Supplementary irrigation (using knapsack for surface wetting and drip method for underground wetting) is usually carried out to overcome prolonged drought $(\overline{\mathbf{X}}=2.54)$. Increase in the use of herbicides for weed control $(\overline{\mathbf{X}}=2.68)$. Many watermelon farmers however sought spiritual interventions like prayers or use of god of thunder (elegun sango) on the watermelon farms for rain $(\overline{\mathbf{X}}=1.43)$.

Table-3. Distribution according to coping strategies $(\mathrm{n}=150)$

\begin{tabular}{|c|c|c|c|c|}
\hline Coping strategies adopted & Always used & Seldom used & Not used & Mean \\
\hline $\begin{array}{l}\text { Adjustment in planting time to dry season (September, } 1 \\
-10)\end{array}$ & $128(85.3)$ & $12(8.0)$ & $10(6.7)$ & 2.79 \\
\hline $\begin{array}{l}\text { Expanding of planting space from } 90 \mathrm{~cm} \times 90 \mathrm{~cm} \text { apart to } \\
1 \mathrm{~m} \times 1 \mathrm{~m} \text { to allow rapid vines development }\end{array}$ & $96(70.7)$ & $30(20.0)$ & $24(9.3)$ & 2.48 \\
\hline $\begin{array}{l}\text { Importation of improved seeds from Togo and other } \\
\text { neighbouring countries as against use of certified seeds } \\
\text { in the country (500mg tin) }\end{array}$ & $75(50.0)$ & $50(33.3)$ & $25(16.7)$ & 2.33 \\
\hline $\begin{array}{l}\text { Increase in spot application of urea fertilizer }(2- \\
\text { 3bags/ha) second week after planting }\end{array}$ & $106(44.0)$ & $26(30.7)$ & $18(25.3)$ & 2.59 \\
\hline $\begin{array}{l}\text { Increased use of folial fertilizer in combination with } \\
\text { insecticide and fungicide at every } 8 \text { days interval to } \\
\text { suppress pest and diseases infestation }(5-6 \text { times before } \\
\text { harvest) }\end{array}$ & $92(40.0)$ & $38(33.3)$ & $10(26.7)$ & 2.41 \\
\hline $\begin{array}{l}\text { Supplementary irrigation (using knapsack for surface } \\
\text { wetting and drip method for underground wetting) to } \\
\text { overcome prolonged drought }\end{array}$ & $96(64.0)$ & $40(26.7)$ & $14(9.3)$ & 2.54 \\
\hline Use of mulching to retain soil moisture content & $12(8.0)$ & $34(22.7)$ & $104(69.3)$ & 1.39 \\
\hline Increase in the use of herbicides for weed control & $114(76.0)$ & $24(16.0)$ & $12(8.0)$ & 2.68 \\
\hline $\begin{array}{l}\text { Spiritual interventions like prayers or use of god of } \\
\text { thunder (elegun sango) on the farms for rain }\end{array}$ & $13(8.7)$ & $39(26.0)$ & $98(65.3)$ & 1.43 \\
\hline
\end{tabular}

\subsection{Sources of Information on Coping Strategies}

Information is one of the most valuable resources for the agricultural growth and development in the rural areas of Nigeria, and in recent time it has been described as fifth factor of production. The result showed that the most $(90 \%)$ of the watermelon farmers accessed information through fellow farmers $(\overline{\mathbf{X}}=2.90)$, Watermelon Farmers Association $(\overline{\mathbf{X}}=2.83)$ and friends and neighbours $(\overline{\mathbf{X}}=2.20)$ and these were accordingly ranked $1^{\text {st }}, 2^{\text {nd }}$ and $3^{\text {rd }}$ respectively. This implies that information on coping strategies to climate change are obtained through interaction by the watermelon farmers and sharing of what individual experienced on the farms. This serves as first hand information to the farmers which led to acceptance of such measures against adverse climatic condition. Abiona, (2010) cited in Omoare et al. (2016) reported that sources through which information reached the farmers have influence in the decision to accept or reject an innovation. But media $(\overline{\mathbf{X}}=1.68)$ and extension agents $(\overline{\mathbf{X}}=$ $1.35)$ were the least channels through which information relating to climate change, coping strategies and improved practices on watermelon production are diffused to the farmers. 
Table-2. Sources of Information on coping strategies $(\mathrm{n}=150)$

\begin{tabular}{l|l|l|l|l|l}
\hline Sources of information on coping strategies & Always & Occasionally & Never & Mean & Rank \\
\hline Extension agents & $10(6.7)$ & $32(21.3)$ & $108(72.0)$ & 1.35 & $5^{\text {th }}$ \\
\hline Media (Radio, Television and Newspapers) & $29(19.3)$ & $44(29.3)$ & $77(51.4)$ & 1.68 & $4^{\text {th }}$ \\
\hline Watermelon Farmers Association & $124(82.7)$ & $18(12.0)$ & $08(5.3)$ & 2.83 & $2^{\text {nd }}$ \\
\hline Fellow farmers & $135(90.0)$ & $15(10.0)$ & $0(0.0)$ & 2.90 & $1^{\text {st }}$ \\
\hline Friends and Neighbours & $63(42.0)$ & $54(36.0)$ & $33(22.0)$ & 2.20 & $3^{\text {rd }}$ \\
\hline
\end{tabular}

Source: Field survey, 2016

\subsection{Test of Hypotheses}

\subsubsection{Association between Respondent's Personal Characteristics and Coping Strategies Adopted}

The results of chi-square analysis shows that age $\left(\chi^{2}=41.11, \mathrm{df}=4, \mathrm{p}=0.03\right)$, sex $\left(\chi^{2}=18.32, \mathrm{df}=2, \mathrm{p}=0.00\right)$, educational status $\left(\chi^{2}=25.15, \mathrm{df}=6, \mathrm{p}=0.04\right)$, farming experience $\left(\chi^{2}=39.05, \mathrm{df}=4, \mathrm{p}=0.04\right)$ and farm size $\left(\chi^{2}=\right.$ $43.27, \mathrm{df}=2, \mathrm{p}=0.01$ ) were significant to coping strategies adopted by the watermelon farmers at $\mathrm{p}<0.05$ level of significance. This implies that significant association existed between personal characteristics and coping strategies. It means personal characteristics variables such as age, sex, educational status, farming experience and farm size have influence on coping strategies adopted by watermelon farmers. Therefore, the null hypothesis that "there is no significant association between respondent's personal characteristics and coping strategies adopted" is rejected.

Table-4. Association between respondent's personal characteristics and coping strategies adopted

\begin{tabular}{|c|c|c|c|c|}
\hline Variables & $\chi^{2}$ & df & p-value & Decision \\
\hline Age & 41.11 & 4 & 0.03 & $\mathrm{~S}$ \\
\hline Sex & 18.32 & 2 & 0.00 & $\mathrm{~S}$ \\
\hline Educational s atus & 25.15 & & $\mathrm{O} \quad \mathrm{O} 4$ & $\mathrm{~S}$ \\
\hline Farming Experience (yrs.) & 39.05 & 4 & 0.00 & $\mathrm{~S}$ \\
\hline $\mathrm{Fa} \mathrm{m}$ size & 43.27 & 2 & 0.01 & $\mathrm{~S}$ \\
\hline
\end{tabular}

\subsection{Relationship between Sources of Information and Coping Strategies Adopted}

The result of chi-square analysis indicates that significant relationship existed between sources of information and coping strategies adopted at $\mathrm{p}<0.05$ level of significance. That is, sources of information such as Watermelon Farmers Association $\left(\chi^{2}=189.0, \mathrm{df}=4, \mathrm{p}=0.00\right)$, fellow farmers $\left(\chi^{2}=125.4 \mathrm{df}=4, \mathrm{p}=0.02\right)$ and friends and neighbours $\left(\chi^{2}=211.2, \mathrm{df}=4, \mathrm{p}=0.00\right)$ had positive and significant to coping strategies adopted by the watermelon farmers at $\mathrm{p}<0.05$ level of significance. It means that respondents' access to information through these channels has helped in checkmating the adverse effect of climate change in the watermelon production in the study area. But, extension agents $\left(\chi^{2}=14.3, \mathrm{df}=4, \mathrm{p}=0.06\right)$ and media $\left(\chi^{2}=11.1, \mathrm{df}=4, \mathrm{p}=0.09\right)$ were not significant. This implies that extension agents and media are not effective in disseminating information relating to watermelon and effect of climate change to farmers in the study area. Therefore, the null hypothesis that "there is no significant relationship between sources of information and coping strategies adopted" is rejected.

Table-5. Relationship between sources of information and coping strategies adopted

\begin{tabular}{|c|c|c|c|c|}
\hline Variables & $\chi^{2}$ & df & p-value & Decision \\
\hline Extension agents & 14.3 & 4 & 0.06 & $\mathrm{NS}$ \\
\hline Media (Radio, Television and Newspapers) & 11.1 & 4 & 0.09 & NS \\
\hline Watermelon Farmers Association & 189.0 & 4 & 0.00 & $\mathrm{~S}$ \\
\hline Fellow farmers & 125.4 & 4 & 0.02 & $\mathrm{~S}$ \\
\hline Friends and Neighbours & 211.2 & 4 & 0.00 & $\mathrm{~S}$ \\
\hline
\end{tabular}

\section{CONCLUSION AND RECOMMENDATIONS}

This study concludes that climate change did not only led to pest and diseases infestation of the farms, deformed pods, crop failure but also affected the yield and income of the watermelon farmers in the study area. The 
farmers in a bid to ameliorate adverse effects of climate change adopted coping strategies like changing of planting date, increasing urea and folia fertilizer application, supplementary irrigation and frequent spraying with agrochemicals. The predominant sources of information on coping strategies are watermelon farmers association, fellow farmers, and friends and neighbours. Moreover, significant relationships existed between personal characteristics of the respondents and coping strategies adopted by the watermelon farmers. In the same vein, sources of information and coping strategies adopted to minimize effect of climate change had significant relationship.

\section{RECOMMENDATIONS}

Based on the findings of this study it is hereby recommends that:

i. Effort should be put in place by the government and seed council of Nigeria to come up with improved and high drought and disease resistant watermelon seeds to reduce cost of importation;

ii. Extension service providers should create more awareness on the adverse effect of climate change and proffer possible measures to minimize these effects in the study area;

iii. Watermelon farmers should as well not relent effort to access relevant information on climate change and to use their association platform to reach out to their colleagues particularly in the remote areas in order to come out of adverse effect of climate change in the study area; and

iv. Media should also help to disseminate information regarding climate change to the watermelon farmers study area.

Funding: This study received no specific financial support.

Competing Interests: The authors declare that they have no competing interests.

Contributors/Acknowledgement: All authors contributed equally to the conception and design of the study.

\section{REFERENCES}

Adebayo, O.O., 2012. Determinants of climate change and coping strategies among crop farmers in Ondo State, Nigeria. Agricultural Research and Reviews, 1(4): 127 -131. View at Google Scholar

Adejumo, S.A., 2004. The impact of climate variability and climate change on crop yield in Nigeria. Statehoods Workshop on Assessment of Impact and Adaptation to Climate Change (AIACC) Obafemi Awolowo university, Ile Ife, Nigeria.

Agboola, T. and D. Ojeleye, 2007. Climate change and food production in Ibadan, Nigeria Afi. Crop Science-Conference Proudly, 8:1423-1433.

Cardinale, B.J., 2012. Biodiversity loss and its impact on humanity. Nature, 486(7401): 59 - 67. View at Google Scholar|View at Publisher Challinor, A.J., J. Watson, D.B. Lobell, S.M. Howden, D.R. Smith and N. Chhetri, 2014. A meta-analysis of crop yield under climate change and adaptation. Nature Climate Change, 4(4): 287-291. View at Google Scholar |View at Publisher

FAO, 2009. Climate change in Africa: The threat to agriculture. Rome: FAO.

Food and Agriculture Organization (FAO), 2010. Retrieved from www.fao.org.

Intergovernmental Panel on Climate Change, 2007. Summary for policymakers In: Climate change. The physical science basis contribution of working group 1. Fourth Assessment Report of the Intergovernmental Panel on Climate Change, Solomon, S. D., Qin, M., Manning, Z., Chen, M., Marquis, K., B. Avery, M. Tignor, and H. L. Miller (Eds.) United Kingdom and New York, USA. Cambridge University Press, Cambridge. pp: 1000.

Obioha, E., 2008. Climate change, population drift and violent conflict over land resources in North Eastern Nigeria. Journal of Human Ecology, 23(4): 311-342. View at Google Scholar | View at Publisher

Omoare, A.M., W.O. Oyediran and E.O. Fakoya, 2016. Comparative assessment of cocoa farmers' knowledge and attitude towards training on improved cultural management practices in Ogun and Ondo States, Nigeria. International Journal of Agricultural Extension and Rural Development Studies, 3(3): 36 - 51. 
Oyediran, W.O., A.M. Omoare and A.A. Ajagbe, 2016. Factors affecting sustainability of melon (egusi) production in rural farming households of Southwest, Nigeria. American Journal of Agricultural Research, 1(1): 0001 - 0012.

Oyekale, A.S., 2009. The effects of climate on cocoa production and vulnerability assessment in Nigeria. Agriculture Journal, 4(2): 77-85. View at Google Scholar

Prohens, J. and F. Nuez, 2008. Vegetables I. Handbook of plant breeding. Springer: New York, USA. pp: 426.

Wani, A.A., D. Kaur, I. Ahmed and D.S. Sogi, 2008. Extraction optimization of watermelon seed protein using response surface methodology. Food Science Technology, 41(8): 1514 - 5120. View at Google Scholar | View at Publisher

Williams, S.E., L.P. Shoo, J.L. Isaac, A.A. Hoffmann and G. Langham, 2008. Towards an integrated framework for assessing the vulnerability of species to climate change. Biology, 6(12): 262 1-2626. View at Google Scholar | View at Publisher

Views and opinions expressed in this article are the views and opinions of the author(s), International Journal of Sustainable Agricultural Research shall not be responsible or answerable for any loss, damage or liability etc. caused in relation to/arising out of the use of the content. 